\title{
A longitudinal study of Campylobacter distribution in a turkey
} production chain

\author{
Päivikki Perko-Mäkelä* ${ }^{1}$, Pauliina Isohanni ${ }^{2}$, Marianne Katzav, \\ Marianne Lund ${ }^{3}$, Marja-Liisa Hänninen ${ }^{4}$ and Ulrike Lyhs ${ }^{2}$
}

\begin{abstract}
Address: ${ }^{1}$ Finnish Food Safety Authority Evira, Research Department, Production Animal Health, PO Box 198, FI-60101 Seinäjoki, Finland, ${ }^{2}$ Ruralia Institute, Seinäjoki Unit, University of Helsinki, Kampusranta 9C, FI-60320 Seinäjoki, Finland, ${ }^{3}$ National Veterinary Institute, Technical University of Denmark, Hangøvej 2, DK-8200 Århus N, Denmark and ${ }^{4}$ Department of Food and Environmental Hygiene, Faculty of Veterinary Medicine, University of Helsinki PO Box 61, FI-00014 University of Helsinki, Finland
\end{abstract}

E-mail: Päivikki Perko-Mäkelä* - paivikki.perko-makela@evira.fi; Pauliina Isohanni - pauliina.isohanni@helsinki.fi; Marianne Katzav - marianne.katzav@helsinki.fi; Marianne Lund - marlu@vet.dtu.dk; Marja-Liisa Hänninen - marja-liisa.hanninen@helsinki.fi; Ulrike Lyhs - ulrike.lyhs@helsinki.fi

*Corresponding author

Published: 07 April 2009

Acta Veterinaria Scandinavica 2009, 5I:18 doi: 10.1186/175I-0147-5I-18

This article is available from: http://www.actavetscand.com/content/5I/I//8

(C) 2009 Perko-Mäkelä et al; licensee BioMed Central Ltd.

This is an Open Access article distributed under the terms of the Creative Commons Attribution License (http://creativecommons.org/licenses/by/2.0), which permits unrestricted use, distribution, and reproduction in any medium, provided the original work is properly cited.
Received: 18 December 2008

Accepted: 7 April 2009

\begin{abstract}
Background: Campylobacter is the most common cause of bacterial enteritis worldwide. Handling and eating of contaminated poultry meat has considered as one of the risk factors for human campylobacteriosis.Campylobacter contamination can occur at all stages of a poultry production cycle. The objective of this study was to determine the occurrence of Campylobacter during a complete turkey production cycle which lasts for I,5 years of time. For detection of Campylobacter, a conventional culture method was compared with a PCR method. Campylobacter isolates from different types of samples have been identified to the species level by a multiplex PCR assay.

Methods: Samples $(N=456)$ were regularly collected from one turkey parent flock, the hatchery, six different commercial turkey farms and from II different stages at the slaughterhouse. For the detection of Campylobacter, a conventional culture and a PCR method were used. Campylobacter isolates $(n=143)$ were identified to species level by a multiplex PCR assay.

Results: No Campylobacter were detected in either the samples from the turkey parent flock or from hatchery samples using the culture method. PCR detected Campylobacter DNA in five faecal samples and one fluff and eggshell sample. Six flocks out of 12 commercial turkey flocks where found negative at the farm level but only two were negative at the slaughterhouse.

Conclusion: During the brooding period Campylobacter might have contact with the birds without spreading of the contamination within the flock. Contamination of working surfaces and equipment during slaughter of a Campylobacter positive turkey flock can persist and lead to possible contamination of negative flocks even after the end of the day's cleaning and desinfection. Reduction of contamination at farm by a high level of biosecurity control and hygiene may be one of the most efficient ways to reduce the amount of contaminated poultry meat in Finland. Due to the low numbers of Campylobacter in the Finnish turkey production chain, enrichment PCR seems to be the optimal detection method here.
\end{abstract}




\section{Background}

Campylobacter is the most common cause of bacterial enteritis worldwide. Commonly recognized risk factors are drinking surface water or water from private wells, swimming in natural waters, and drinking unpasteurised milk [1-5]. However, meat and especially the handling and consumption of undercooked poultry meat are considered as main risk factors for human campylobacteriosis [6-8].

Campylobacter contamination can occur at all stages of a poultry production cycle. In studies concerning vertical transmission, C. jejuni has been found on both outer and inner egg shell surfaces $[9,10]$ and in the reproductive tract of laying and broiler breeder hens $[11,12]$. Hiet et al. [13] have shown the presence of Campylobacter DNA in fluff and eggshell samples. In contrast, Petersen et al. [14] and Herman et al. [15] reported no findings of Campylobacter from different samples collected in the hatchery e.g. incubator content, swab samples from hatchery machinery and floors and yolk sacs of diseased or dead chicks. Despite these observations, there is no clear evidence that vertical transmission or horizontal hatchery transmission does occur $[14,16]$.

Many studies have provided strong evidence that the farm environment serves as a reservoir for the Campylobacter colonising poultry flocks. Dogs and other farm animals, wild birds, flies and untreated water may play a role in transmission of Campylobacter [17-21]. The prevalence of Campylobacter in broiler flocks varies in the different areas. Nordic countries like Finland, Sweden, Norway and Iceland have reported relatively low prevalences of 2,9\%,27\%, 18\% and 27,5\% respectively [22-24]. In contrast, studies from other countries showed much higher occurrences of Campylobacter at the farm level, for example, $87.5 \%$ in the USA [25] and 42.7\% in France [26]. Limited work has been carried out on investigating the prevalence of Campylobacter in the turkey production chain. Cox et al. [27] showed positive findings of $77 \%$ in male and $80 \%$ in female turkeys at 15 weeks of age. Other studies reported $48 \%$ and more than $80 \%$ of positive turkey flocks at the time of slaughter $[28,29]$.

In spite of current cleaning and disinfection procedures, transport crates may be contaminated with Campylobacter, which may in turn contaminate birds during transport from the farm to the slaughterhouse [30,31]. During the slaughter process, contamination of the poultry carcasses and the equipment with Campylobacter occurs during defeathering, evisceration and the chilling processes $[25,32]$. Air also is found as a potential source of contamination at the slaughterhouse [33]. Contamination of turkey carcasses with Campylobacter at slaughter has been reported with levels of between $35 \%$ and $91.7 \%$ [34-37].

The aim of this study was to determine the occurrence of Campylobacter during one total turkey production cycle of 1,5 years time period, starting from imported parents (day-old chicks) to slaughter. For detection of Campylobacter at all stages of the production chain, a conventional culture method was compared with a PCR method. Campylobacter isolates from different types of samples have been identified to species level by a multiplex PCR assay.

\section{Materials and methods}

Study population and turkey production cycle

Between April 2005 and October 2006, one total turkey production cycle was studied. One cycle was defined as follows: Day-old parent chicks are imported from the UK. They are kept in parent rearing farms for 28 weeks. Before they start laying, the turkeys are transported to brooding farms, where they stay for 24 weeks. All the eggs they lay at the brooding farm are hatched in one hatchery. Day-old turkey chicks are transported to commercial farms. Turkey females and males are reared in the same house but separated by various types of walls. Following the slaughter of the females at 13-15 weeks, the males are allowed to use the entire house. Males are slaughtered at an age of 17-18 weeks.

At the parent rearing farm, the flock size was 2,700 and at the brooding farms the flock size was 2,300. Hatchery capacity was 900,000 poults per year. The size of the commercial farms varied from 6,000 to 18,000 birds per cycle. The slaughterhouse slaughtered only turkeys and the capacity was 3,500-5,000 birds/day. Only one flock was slaughtered per day.

\section{Collection and transport of the samples}

All samples were collected on each occasion within $2 \mathrm{~h}$, placed in a cool box and transported immediately to the laboratory, where they were processed within 2-4 h. Processing varied depending on the type of samples. Table 1 presents types and numbers of samples taken during this study.

For transporting swab samples from the farms and the slaughterhouse, each swab was put into a tube containing $37 \mathrm{~g} \mathrm{l}^{-1}$ Brain Heart Infusion Broth (LabM, Lancashire, UK) with 5\% calf blood and $0.5 \%$ agar (Scharlau-Chemie, Barcelona, Spain) and stored at $4^{\circ} \mathrm{C}$. In the laboratory, the swabs were placed into tubes containing $3 \mathrm{ml}$ physiological saline $(0.85 \% \mathrm{NaCl}, \mathrm{w} / \mathrm{v})$ and left to stand for five to $10 \mathrm{~min}$ to suspend bacteria before further processing. 
Table I: Places of sampling, types and numbers of samples taken during one total turkey production cycle

\begin{tabular}{lll}
\hline Place of sampling & Type of samples & $\begin{array}{l}\text { Number of } \\
\text { samples }(\mathrm{n})\end{array}$ \\
\hline $\begin{array}{l}\text { Farm } \\
\text { - Parent rearing farm }\end{array}$ & $\begin{array}{l}\text { Paper liners, swabs from faecal } \\
\text { droppings }\end{array}$ & 80 \\
- Parent brooding farm & $\begin{array}{l}\text { Swab samples from droppings } \\
\text { - Rearing farm }\end{array}$ & 70 \\
Swab samples from droppings & 360 \\
Hatchery & Eggshells and fluff & 30 \\
Slaughterhouse & $\begin{array}{l}\text { Caecal samples } \\
\text { Environmental samples (swabs, }\end{array}$ & 336 \\
& $\begin{array}{l}\text { water, faecal material) } \\
\text { Neck skin samples }\end{array}$ & 120 \\
& Meat samples & 60 \\
\hline Total number of samples $(\mathrm{N})$ & 456 \\
\hline
\end{tabular}

Sterile gauze swabs $(10 \times 10 \mathrm{~cm})$ were used to collect samples from the surfaces at the slaughter and meatcutting departments. Before use, they were pre-moistened in Bolton selective enrichment Broth (Oxoid CM0983, Hampshire, UK) without supplement, placed in a sterile jar and stored at $4{ }^{\circ} \mathrm{C}$.

At the slaughterhouse, all environmental, neck skin and caecal samples were collected during the slaughtering process. At the same time, swab samples were collected from the transportation crates after disinfection and from the rubber boots of the workers in the evisceration room. Gauze samples were taken from different surfaces of the evisceration and cutting room and from the floor of the chilling room. All meat samples and environmental samples from the meat-cutting department were taken on the day of processing.

Process water samples of one litre were collected during the slaughter of each flock concerned from the defeathering machine and the chilling tank, respectively, into sterile plastic bottles.

\section{Samples}

Faecal samples from parent rearing, brooding and commercial farms

At the first time of sampling in the parent rearing farm, ten samples were taken from the chick transportation bed including paper liners and faecal droppings. Thereafter ten swab samples were collected from fresh faecal droppings once every month over a period of seven months. After transfer of the birds to the brooding farm, ten swab samples were taken from fresh faecal droppings once every month, over a period of seven months. One swab was put into one transport tube. For enrichment, five swabs were pooled together to create two subsamples.

One to two weeks prior to the slaughter of females and males, 20 swab samples were taken from fresh faecal droppings at six rearing farms. The farms were randomly coded A to F. Five swabs were pooled together to create four subsamples. For enrichment, these four samples were pooled together.

\section{Hatchery samples}

Ten samples containing eggshell and fluff were taken three times over a period of three weeks and collected into separate plastic bags. In the laboratory, $20 \mathrm{~g}$ of each sample were measured into $180 \mathrm{ml}$ Bolton selective enrichment broth (Oxoid CM0983, Hampshire, UK) with selective supplement (Oxoid SR0183) and 5\% lysed horse blood for enrichment. In addition, $1 \mathrm{~g}$ was put into $10 \mathrm{ml}$ physiological saline $(0.85 \% \mathrm{NaCl})$ and left to stand for $10 \mathrm{~min}$.

\section{Caecal samples at the slaughterhouse}

Ten caeca were taken at the evisceration line during the slaughter of each flock in question. Five caeca at a time were placed into one transport container. In the laboratory, each caecum was opened aseptically and swab samples from each caecum were taken. Five swabs were pooled to create two subsamples.

\section{Environmental samples at the slaughterhouse}

A total of 336 environmental samples were collected, consisting of swab, water, and faecal samples. The various sampling methods are described below:

A total of 180 gauzes were pre-moistened in Bolton broth (without supplement) and the different surfaces were wiped vigorously for $30 \mathrm{~s}$. Gauzes were placed into a jars with $50 \mathrm{ml}$ Bolton broth, without supplement. In the laboratory, $50 \mathrm{ml}$ Bolton Broth with supplement was added to jars and mixed. The water samples were filtered in the laboratory through $0.45 \mu \mathrm{m}$ filters (Fennolab, Vantaa, Finland) and four to eight filters were placed into 15-20 ml Bolton Broth (with supplement). Twentyfour litres of water were collected.

Faecal material from the transport crates was collected into a plastic bag. In the laboratory, $5 \mathrm{~g}$ of the material were placed into $45 \mathrm{ml}$ Bolton broth (with supplement). A total of 12 faecal material samples were collected. Swab samples were collected as described earlier from transport crates (after disinfection) and from rubber boots in the evisceration room. Five swabs were pooled to create one sample. 
Neck skin and meat samples at the slaughterhouse

Ten samples of neck skin were collected during the slaughter of each flock concerned. Furthermore, five meat samples consisting of a variety of cuts were collected separately into plastic bags from the meatcutting department. In the laboratory, $25 \mathrm{~g}$ of neck skin ( 2 pooled samples of five times $5 \mathrm{~g}$ each) or meat (five separate samples $5 \mathrm{~g}$ each) were aseptically transferred into a Stomacher ${ }^{\circledR} 400$ bag (Seward BA6041, Worthing, UK) containing $225 \mathrm{ml}$ Bolton broth (with supplement) and shaken manually for $3 \mathrm{~min}$.

\section{Culture method for detection of Campylobacter}

All samples were tested by both direct plating and enrichment culture. Direct plating and isolation after enrichment was done on modified charcoal cefoperazone deoxycholate agar plate (mCCDA) (Oxoid CM739) supplemented with SR 155 (Oxoid). Plates were incubated at $42 \pm 1^{\circ} \mathrm{C}$ for $48 \pm 4 \mathrm{~h}$ under microaerobic conditions $\left(5 \% \mathrm{O}_{2}, 10 \% \mathrm{CO}_{2}, 85 \% \mathrm{~N}_{2}\right)$, generated by CampyGen $^{\mathrm{TM}}$ (Oxoid CN0035). For enrichment, Bolton selective enrichment broth (Oxoid CM0983) with selective supplement (Oxoid SR0183) and 5\% lysed horse blood was used and incubated at $42 \pm 1^{\circ} \mathrm{C}$ for $22 \pm 2 \mathrm{~h}$ under microaerobic conditions generated by CampyGen $^{\mathrm{TM}}$ (Oxoid). The same enrichment and plating procedure was used for all samples described above.

\section{PCR method for detection of Campylobacter}

For PCR, aliquots of $1 \mathrm{ml}$ saline or Bolton broth, respectively, were collected from all samples both directly and after enrichment and centrifuged at 13,000 rpm for $8 \mathrm{~min}$ at room temperature. The supernatant was removed carefully and the pellet frozen at $-80^{\circ} \mathrm{C}$. DNA isolation from the frozen pellet was carried out using a DNA isolation kit, MagneSil ${ }^{\circledR}$ KF Genomic System (Promega MD1460, Madison, WI, USA), with a Dynal $\mathrm{MPC}^{\circledR}$-S magnetic stand (Dynal Biotech, Oslo, Norway) as described in Katzav et al. [38]. The detection of Campylobacter spp. in the samples was based on amplification of the 16S rRNA gene [39] using a set of oligonucleotide primers: C412F 5'-GGA TGA CAC TTT TCG GAG C-3' and 16S rRNA-campR2 5'-GGC TTC ATG CTC TCG AGT T-3' as described by Linton et al 1996 and Lund et al. [40], respectively. The internal amplification control (IAC) was prepared by isolating genomic DNA from the bacterium Yersinia ruckeri which is the causative agent of enteric redmouth disease in salmonid fish species [41]. This bacterium is not found naturally in chickens. For detection of the internal control, the primers Yers F8 5'-CGA GGA GGA AGG GTT AAG TG3' and Yers R10 5'-AAG GCA CCA AGG CAT CTC TG-3' slightly modified from Gibello et al. [41] and slightly modified were used. All the primers were synthesised by
Oligomer Oy (Helsinki, Finland). The PCR conditions used in the present study are described by Lund et al. [40] with a few modifications. Briefly, the PCR amplification was performed in $50 \mu$ l volumes containing $5 \mu \mathrm{l}$ of the DNA, $25 \mu \mathrm{l}$ of a PCR master mix (Promega, Madison, WI, USA), $1 \mu$ l of a $25 \mathrm{mM} \mathrm{MgCl}_{2}$ solution, $0.5 \mu \mathrm{l}$ of a $10 \mathrm{mg} \mathrm{ml}^{-1}$ BSA solution (New England Biolabs, Ipswich, MA, USA), 20 pmol of each of the Campylobacter primers and $5 \mathrm{pmol}$ of each of the internal control primers and $10 \mathrm{pg}$ of genomic Yersinia ruckeri DNA primers. The PCR was performed in a Peltier Thermal Cycler (PTC-200; MJ Research Inc., Watertown, MA, USA) and the conditions were one cycle of $95^{\circ} \mathrm{C}$ for 2 minutes, $58^{\circ} \mathrm{C}$ for 1 minutes, $72^{\circ} \mathrm{C}$ for 1 minute, followed by 34 cycles of $95^{\circ} \mathrm{C}$ for 15 seconds, $58^{\circ} \mathrm{C}$ for 40 seconds and $72^{\circ} \mathrm{C}$ for 40 seconds. The last elongation step lasted 5 minutes. The PCR product was loaded onto a $2 \%$ agarose gel (1.35\% SeaKem ${ }^{\circledast}$ LE Agarose and $0.65 \%$ NuSieve GTG Agarose, Cambrex Bio Science, Rockland, ME, USA) containing $0.1 \mathrm{~g} \mathrm{ml}^{-1}$ ethidium bromide. A DNA molecular weight marker 100 bp low ladder (P1473, Sigma-Aldrich, Saint Louis, MO, USA) was included in each gel. The gel was photographed under UV light (Alpha DigiDoc, Alpha Innotech, San Leandro, CA, USA). The PCR reaction for each sample was performed twice and considered positive if the primer set gave a distinct band of the right size (857 bp). Samples with no internal control band were run again using a tenfold dilution of DNA.

For sequencing of bands visible on the gel, PCR fragments was purified from the gel using an Qiaquick PCR purification kit (Qiagen GmbH Hilden, Germany) and sent for sequencing at DNA technology (Århus, Denmark) using the same primers for sequencing as used for the PCR. The homology of the sequenced PCR fragments to other Campylobacter sequences was determined using BLAST Sequence alignments.

\section{Identification of Campylobacter spp. isolates}

Up to three Campylobacter-like colonies from each positive sample from rearing farms and slaughterhouse were selected, subcultured on mCCDA agar without supplement and incubated as described above. Identification to genus level was performed according to the method of the National Committee of Food Analyses [42]. To test their ability to grow in air, the colonies were streaked out onto blood plates (CASO agar, CaseinPeptone Soymeal-Peptone, Merck, Darmstadt, Germany with $5 \%$ bovine blood) and incubated aerobically at $37^{\circ}$ C for up to three days.

For identification to species level, a multiplex PCR assay and two sets of primers based on the method described 
by Vandamme et al. [43] were used. The isolates were cultured on mCCDA agar without supplement and mixed with $20 \mu \mathrm{l}$ of water and kept for $10 \mathrm{~min}$ at $100^{\circ}$ C. The first primer set was C. coli specific, COL1 (5'-AG GCA AGG GAG CCT TTA ATC-3') and COL2 (5'-TAT CCC TAT CTA CAA ATT CGC-3') and the second set $C$. jejuni specific, JUN3 (5'-CA TCT TCC CTA GTC AAG CCT-3') and JUN4 (5'-AAG ATA TGG CTC TAG CAA GAC 3'). All primers were synthesised by Oligomer Oy (Helsinki, Finland). PCR amplification was performed in $25 \mu \mathrm{l}$ volumes containing $3 \mu \mathrm{l}$ of template, $12.5 \mu \mathrm{l}$ of a PCR master mix (Promega, Madison, WI, USA), $1.5 \mu \mathrm{l}$ of water and 20 pmol of each primer. PCR was performed in a Peltier Thermal Cycler (PTC-200; MJ Research Inc., Watertown, MA, USA) and the conditions were according to Vandamme et al. [43]. A DNA molecular weight marker 100 bp low ladder (P1473, Sigma-Aldrich, Saint Louis, MO, USA) was included in each gel. The gel was photographed under UV light (Alpha DigiDoc, Alpha Innotech, San Leandro, CA, USA).

\section{Data management and calculations}

For data management and calculations Microsoft ${ }^{\circledR}$ Excel 97 SR 2 was used. The level of agreement according to precision was expressed as the kappa statistic, defined as the proportion of potential agreement beyond chance exhibited by two tests. Diagnostic specificity was calculated as: $d /(b+d)$ where $d$ is the number of samples negative both by PCR and by culture and $b$ is the number of samples positive by PCR, but negative by culture. The level of agreement between two tests was calculated as: $(a+d) / n$, where $a$ is the number of samples positive both by PCR and by culture, $d$ is the number of samples negative by both methods and $n$ is the total number of samples under examination $[44,45]$.

\section{Results}

None of the 150 samples from the turkey parent flock, collected during the rearing and brooding period, and of the 30 samples from the hatchery were Campylobacter positive either by direct culture or culture following enrichment. However, using the PCR method, five samples from the parent flock in the brooding farm and one sample from the hatchery were Campylobacter positive. The PCR products from these samples were sequenced and identified as C. jejuni.

Table 2 shows the number of positive faecal samples in the six commercial farms (A-F) studied by culture and PCR method. Three farms (A, C and E) were found to be colonised with Campylobacter prior to slaughter. At farms A and E, both females and males were found positive. From farm C, only samples from the females were found Campylobacter positive whereas the males were negative at the first sampling. After transport of the females from farm $\mathrm{C}$ to the slaughterhouse, the male flock also became colonised with Campylobacter. No Campylobacter were found in the three other farms (B, D and F) either by direct and enrichment culture or by PCR method.

Table 3 provides details of the percentage of Campylobacter in the flocks at slaughter and at meat cutting. At the slaughterhouse, Campylobacter was isolated from at least one sample in 10 out of the 12 flocks studied. However, from two female flocks of the farms B and D no Campylobacter was detected. The female flock of farm $\mathrm{B}$ was Campylobacter negative also by PCR method, but

Table 2: Campylobacter colonisation in Finnish turkey rearing farms one to two weeks prior to slaughter and comparison of the conventional culture and PCR method for the detection of Campylobacter

\begin{tabular}{|c|c|c|c|c|c|c|c|c|c|}
\hline \multirow[t]{2}{*}{ Sampling month } & \multirow[t]{2}{*}{ Farm } & \multicolumn{2}{|c|}{ Direct culture } & \multicolumn{2}{|c|}{ Enrichment culture } & \multicolumn{2}{|l|}{ PCR } & \multicolumn{2}{|c|}{ PCR after enrichment } \\
\hline & & Female & Male & Female & Male & Female & Male & Female & Male \\
\hline July & $\mathrm{A} 1^{1}, \mathrm{~A} 2^{2}$ & $4 / 4^{3}$ & $3 / 4$ & $1 / 1$ & $1 / 1$ & $3 / 4$ & $2 / 4$ & $N^{4}$ & ND \\
\hline August & $\mathrm{A} 2$ & & $3 / 4$ & & $1 / 1$ & & $3 / 4$ & & $1 / 1$ \\
\hline August & $\mathrm{B} 1, \mathrm{~B} 2$ & $0 / 4$ & $0 / 4$ & $0 / 1$ & $0 / 1$ & $0 / 4$ & $0 / 4$ & ND & ND \\
\hline August & B2 & & $0 / 4$ & & $0 / 1$ & & $0 / 4$ & & ND \\
\hline August & $\mathrm{Cl}, \mathrm{C} 2$ & $4 / 4$ & $0 / 4$ & $1 / 1$ & $0 / 1$ & $4 / 4$ & $0 / 4$ & ND & ND \\
\hline September & $\mathrm{C} 2$ & & $3 / 4$ & & $1 / 1$ & & $4 / 4$ & & $1 / 1$ \\
\hline August & D1, D2 & $0 / 4$ & $0 / 4$ & $0 / 1$ & $0 / 1$ & $0 / 4$ & $0 / 4$ & ND & ND \\
\hline September & $\mathrm{D} 2$ & & $0 / 4$ & & $0 / 1$ & & $0 / 4$ & & $0 / 1$ \\
\hline August & EI, E2 & $1 / 4$ & $1 / 4$ & $\mathrm{I} / \mathrm{I}$ & $1 / 1$ & $1 / 4$ & $2 / 4$ & ND & ND \\
\hline September & E2 & & $1 / 4$ & & $1 / 1$ & & $0 / 4$ & & $1 / 1$ \\
\hline September & $\mathrm{FI}, \mathrm{F} 2$ & $0 / 4$ & $0 / 4$ & $0 / 1$ & $0 / 1$ & $0 / 4$ & $0 / 4$ & $0 / 1$ & $0 / 1$ \\
\hline October & $\mathrm{F} 2$ & & $0 / 4$ & & $0 / 1$ & & $0 / 4$ & & $0 / 1$ \\
\hline
\end{tabular}

\footnotetext{
'Number one after the capital indicates female turkeys.

${ }^{2}$ Number two after the capital indicates male turkeys.

${ }^{3}$ Number of positive/number examined.

${ }^{4} \mathrm{ND}$. Not determined.
} 
Table 3: Prevalence of Campylobacter in turkey flocks during slaughter and meat cutting detected by culture and/or PCR method

\begin{tabular}{|c|c|c|c|c|c|c|c|c|}
\hline \multirow[t]{3}{*}{ Farm } & \multicolumn{4}{|c|}{$\begin{array}{l}\text { Processing plant } \\
\text { No. of positive/no. examined (\%) }\end{array}$} & \multicolumn{4}{|c|}{$\begin{array}{l}\text { Meat samples } \\
\text { No. of positive/no. examined (\%) }\end{array}$} \\
\hline & \multicolumn{2}{|l|}{ Female } & \multicolumn{2}{|l|}{ Male } & \multicolumn{2}{|l|}{ Female } & \multicolumn{2}{|l|}{ Male } \\
\hline & Culture' & $P^{\prime} R^{\prime}$ & Culture' & $\mathrm{PCR}^{\prime}$ & Culture' & $P C R^{\prime}$ & Culture' & $\mathrm{PCR}^{\prime}$ \\
\hline A & 9/1। (82) & $7 / 1 I^{2}(64)$ & $10 / 12(83)$ & $1 \mathrm{I} / 12(92)$ & $2 / 5(40)$ & $0 / 5(0)$ & I/5 (20) & I/5 (20) \\
\hline B & $0 / 12(0)$ & $0 / 12^{2}(0)$ & $6 / 12(50)$ & $1 / 12^{2}(8)$ & $0 / 5(0)$ & $0 / 5(0)$ & $0 / 5(0)$ & I/5 (20) \\
\hline C & $12 / 12(100)$ & $12 / 12(100)$ & $10 / 12(83)$ & $10 / 12(83)$ & $4 / 5(80)$ & $2 / 5(40)$ & $3 / 5(60)$ & $2 / 5(40)$ \\
\hline$D$ & $0 / 12(0)$ & $3 / 12(25)$ & $9 / 12(75)$ & $10 / 12(83)$ & $0 / 5(0)$ & $0 / 5(0)$ & $5 / 5(100)$ & $5 / 5(100)$ \\
\hline $\mathrm{E}$ & $5 / 12(42)$ & $6 / 12(50)$ & $10 / 12(83)$ & $10 / 12(83)$ & $0 / 5(0)$ & $2 / 5(40)$ & $2 / 5(40)$ & $3 / 5(60)$ \\
\hline $\mathrm{F}$ & $2 / 12(17)$ & $3 / 12(25)$ & $1 / 12(8)$ & $4 / 12(33)$ & $0 / 5(0)$ & $0 / 5(0)$ & $0 / 5(0)$ & $0 / 5(0)$ \\
\hline
\end{tabular}

'No. of samples tested positive by direct and/or enrichment method.

${ }^{2} \mathrm{PCR}$ not performed after enrichment.

PCR was not performed after enrichment from the samples of this flock. Generally, the percentage of Campylobacter of the samples taken during the slaughter process was higher than of those taken during the cutting process. In contrast, the meat samples of the males from farm D were all positive for Campylobacter, while only $75 \%$ to $83 \%$ the slaughter samples were positive.

Table 4 shows the number of Campylobacter positive samples taken at the processing plan. When using enrichment culture for Campylobacter determination, the highest percentage of positive samples was found in the environmental samples from the evisceration room $(75 \%)$. Also faecal material collected from the transport crates $(67 \%)$, the chilling water $(67 \%)$ and the neck skins $(62.5 \%)$ had high isolation rates after enrichment. Following enrichment, higher percentages of positive samples were observed among neck skin samples $(62.5 \%)$ than among the caecal samples (33\%). Environmental samples from the chilling- and cutting room were all negative by direct culture and direct PCR. However, following enrichment, $50 \%$ and $42 \%$ of the same samples from the chilling room, and $56 \%$ and $56 \%$ from the cutting room were found positive for Campylobacter by culture and PCR, respectively. Also water samples from the defeathering machine, neck skin samples, swab samples from the rubber boots of the workers in the evisceration room and meat cutting samples showed a higher percentage of Campylobacter using PCR after enrichment (Table 4).

A total of 143 Campylobacter isolates from samples taken from the commercial farms and the slaughterhouse were identified as Campylobacter spp. by PCR. When species

Table 4: Occurrence of Campylobacter in samples at different stages and the environment of the slaughter and meat cutting departments detected by culture and PCR method

\begin{tabular}{|c|c|c|c|c|}
\hline & Direct Culture & Enrichment culture & PCR & PCR after enrichment \\
\hline & $\begin{array}{l}\text { No. of positive/ } \\
\text { no. examined (\%) }\end{array}$ & $\begin{array}{l}\text { No. of positive/ } \\
\text { no. examined (\%) }\end{array}$ & $\begin{array}{l}\text { No. of positive/ } \\
\text { no. examined (\%) }\end{array}$ & $\begin{array}{l}\text { No. of positive/ } \\
\text { no. examined (\%) }\end{array}$ \\
\hline Transportation crates & $\mathrm{I} / \mathrm{I} \mathrm{I}^{*}(9)$ & $\mathrm{I} / \mathrm{I} \mid *(9)$ & $\mathrm{I} / \mathrm{I} \mathrm{I}^{*}(9)$ & $1 / 9 *(\mathrm{II})$ \\
\hline Faecal material from transportation crates & $7 / 12(58)$ & $8 / 12(67)$ & $7 / 12(58)$ & $7 / 9(78)$ \\
\hline Water from defeathering machine & $0 / 12(0)$ & $5 / 12(42)$ & $3 / 12(25)$ & $5 / 9(56)$ \\
\hline Caecal material & $9 / 24(37.5)$ & $8 / 24(33)$ & $8 / 24(33)$ & $8 / 18(44)$ \\
\hline Neck skin & $2 / 24(8)$ & $15 / 24(62.5)$ & $6 / 24(25)$ & $12 / 18(67)$ \\
\hline Environment (evisceration room) & $6 / 12(50)$ & $9 / 12(75)$ & $7 / 12(58)$ & $9 / 9(100)$ \\
\hline Rubber Boots (evisceration room) & $3 / 12(25)$ & $6 / 12(50)$ & $3 / 12(25)$ & $5 / 9(56)$ \\
\hline Chilling water & $3 / 12(25)$ & $8 / 12(67)$ & $3 / 12(25)$ & $7 / 9(78)$ \\
\hline Environment (chilling room) & $0 / 12(0)$ & $6 / 12(50)$ & $0 / 12(0)$ & $5 / 9(56)$ \\
\hline Environment (meat cutting room) & $0 / 12(0)$ & $5 / 12(42)$ & $0 / 12(0)$ & $5 / 9(56)$ \\
\hline Meat samples & $0 / 60(0)$ & $17 / 60(28)$ & $4 / 60(7)$ & I3/45 (29) \\
\hline
\end{tabular}

*Eleven samples after washing and disinfection. 
identification was performed using the multiplex PCR method, 105 isolates were identified as C. jejuni and none as C. coli. Thirty-eight isolates were not identified as either C. jejuni or C. coli by the multiplex PCR method. Thirty-four of these isolates originated from different slaughterhouse samples from both female and male flocks from farm C.

The diagnostic specificity for the comparison of direct PCR to direct culture was 0.88 with a level of agreement of 0.88 and for the comparison of both methods by selective enrichment was 0.88 with a level of agreement of 0.92 .

\section{Discussion}

Campylobacter contamination may occur at all stages of a turkey production cycle. In the present study, Campylobacter DNA was detected by PCR from five faecal samples collected during the brooding period. It is likely that the brooding flock had been in contact with Campylobacter but the infection had not spread within the flock. Selflimitation of colonisation and detection of antibodies against C. jejuni without colonisation of the bacterium has previously been described [17].

Detection of Campylobacter DNA by PCR in one fluff and eggshell sample supports the findings of Hiett et al. [13]. The bacterium was not isolated either from the present brooding flocks or from the hatchery and it is not possible to determine whether it is alive or dead. Thus, no further conclusions can be made on vertical transmission based on the present study.

The risk for Campylobacter contamination is high when strict biosecurity barriers are loosened and a poultry flock may come in contact with the environment via people and equipment on the farm. The possibility of compromising biosecurity during partial depopulation or "thinning" has yielded conflicting data. Several authors have demonstrated that the catching team can introduce the bacterium into the house, and therefore, partial depopulation has been considered a risk factor for Campylobacter colonisation [46-48]. In contrast, it has also been demonstrated that it does not necessarily influence Campylobacter colonisation in the flock [49]. At Finnish turkey farms, the flocks are usually divided and females and males are reared in separate groups but in the same house. Females are slaughtered two to four weeks before the males. After the turkey females have been slaughtered, the males can use the area where the females have been. This area could be seen as a risk for contamination since the personnel catching the turkeys can break the hygiene barriers during collection of the female birds. In this study, three flocks were
Campylobacter negative before slaughter of the females and remained negative when testing the males two to three weeks later. Hansson et al. [50] found no differences in the presence of Campylobacter in the environment between producers who frequently or rarely deliver Campylobacter positive slaughter batches. Thus, our results could be explained by good hygiene control of the catching equipment and personnel in the negative farms.

The slaughter process was found to be a risk factor for the Campylobacter contamination of turkey products. The number of Campylobacter positive samples within a flock at slaughter varied between 0 and $94 \%$ in this study. High variation in the turkey flocks at the slaughterhouse has also been demonstrated previously [35,37]. Since enrichment was needed to recover the bacteria, it seems that some processing steps like the scalding and defeathering process had an adverse effect on the bacteria. This study found more positive neck skin samples than caecal samples (Table 3). Neck skins are mentioned as good indicators of Campylobacter contamination at the slaughterhouse [32]. Hansson et al. [31] found more Campylobacter from neck skin samples than from cloacal samples and concluded that if cloacal samples were negative, the neck skin samples might have been contaminated from the slaughterhouse environment. This may also explain the results of the present study.

Evisceration is a critical stage where bacteria can be spread in poultry processing. This fact is confirmed by this study, showing samples from the evisceration room and rubber boots to be 50 to $100 \%$ Campylobacter positive. It has been shown that contamination at the slaughterhouse cannot be avoided when a Campylobacter positive poultry flock is processed [15]. Allen et al. [51] isolated Campylobacter at a slaughterhouse from aerosols, particles and droplets in the hanging, plucking and evisceration areas also during the processing of a Campylobacter negative flock. In this study, all slaughtered birds originated from the same flock and only one flock per day was slaughtered. Thus, cross-contamination from another, potentially positive, flock slaughtered earlier the same day was not possible. However, in this study there is also evidence that contamination at a slaughterhouse can withstand cleaning and disinfection. Flocks B2, D2, F1 and F2 were Campylobacter negative at the farm level, caecum culture-negative at slaughter, but tested positive during the slaughter process. Peyrat et al. [52] also recovered C. jejuni from the equipment surfaces after cleaning and disinfection in three out of four slaughterhouses visited. It is possible that Campylobacter, as well as other bacteria, persist on surfaces in poultryprocessing facilities forming a biofilm [53-55]. Thus, the 
release of the bacterium from such biofilms may also contaminate products which touch the surface of the processing equipment.

In the slaughterhouse studied here, the turkey carcasses were chilled by placing them first in a water tank for five minutes before hanging them for 24 hours in a room at $2{ }^{\circ} \mathrm{C}$. More positive samples from the chilling water than from the chilling room environment were observed, suggesting the chilling water as being a source of carcass contamination. Extended air-chilling might lead to drying of the carcass surface and the environment of the chilling room resulting in a reduction of Campylobacter $[51,56,57]$. In this study, the occurrence of Campylobacter in the samples taken during the meat cutting process was lower than of those taken during the slaughter process. In the present slaughterhouse, the meat was cut the day after slaughter. It is known that certain subpopulations of Campylobacter are able to survive environmental stress like the scalding- and chilling process and remain in the final meat products [58]. However, the low rate of Campylobacter in the final meat products found in the present study $(28 \%)$ is reflected by the low findings in poultry products at the Finnish retail level with reported numbers of $12 \%$ and $21 \%$, respectively $[38,59]$.

Of the 143 Campylobacter spp. isolates, 105 (73\%) were identified as C. jejuni, none as C. coli, so $38(26 \%)$ remained unidentified to the species level. It is known that the majority of the Campylobacter found in raw poultry are C. jejuni $[37,57,60]$. Takahashi et al. [61] found both C. jejuni and C. coli in farm samples, C. jejuni at all stages of the processing line. However, they did not find C. coli anymore after defeathering and speculated lower numbers of $C$. coli in poultry faeces to be the reason. Certain C. jejuni strains might be more stress-resistant and overgrow possible C. coli strains in the same samples [58].

As the high level of agreement between the different detection methods shows, there were no significant differences between the conventional culture and the PCR method in the samples analysed in this study. However, the need for enrichment in this study for the detection of Campylobacter at certain processing steps, also when performing PCR, might indicate low numbers of Campylobacter at the farm and slaughterhouse level. Thus, a combination of enrichment and PCR assay seems to be the optimal method for detection of Campylobacter in this situation.

\section{Conclusion}

The presence of Campylobacter DNA from the brooding flock and hatchery sample shows that they have been in contact with Campylobacter, but for unknown reasons the contamination has not been spread. The present study also shows that during the processing of a Campylobacter positive turkey flock, working surfaces and equipment at the slaughterhouse can become contaminated, leading to possible contamination of negative flocks, even if slaughtered on following days. Persistence of Campylobacter on surfaces emphasises the need for efficient cleaning and disinfection of the processing facilities. However, the need for enrichment in this study for detection of Campylobacter at certain processing steps, also when performing PCR, might indicate low numbers of Campylobacter at the farm and the slaughterhouse level. Since complete elimination of thermophilic Campylobacter from the turkey production chain does not seem feasible, reduction of contamination at the farm level by a high level of biosecurity control and hygiene may be one of the most efficient ways to reduce the amount of contaminated poultry meat in Finland.

\section{Competing interests}

The authors declare that they have no competing interests.

\section{Authors' contributions}

PPM, UL, MK, PI and M-LH participated in the discussion on the study design. PPM, UL, MK and PI participated in the collection of samples, analysis and interpretation of the data. PPM, UL, MK and PI carried out the microbiological analyses of the samples. Analysis and interpretation of the PCR were carried out by PPM. Analysis and interpretation of the sequencing were carried out by ML. PPM and UL wrote the manuscript. All authors read and approved the final manuscript.

\section{Acknowledgements}

The authors wish to thank Dr. Karl Petersen and Dr. Birgitte Borck for their support in planning this project. The authors wish to thank HannaLeena Hietaranta-Luoma for her excellent assistance. The practical assistance from the personnel of Finnish Food Safety Authority Evira, Research Department, Production Animal Health and of the Food and Environmental Laboratory (Seinäjoki, Finland) is gratefully acknowledged. The financial support from the Finnish Funding Agency for Technology and Innovation (TEKES) and the Finnish Cultural Foundation is gratefully acknowledged.

\section{References}

I. Jacobs-Reitsma WF: Campylobacter in the food supply. Campylobacter Washington DC: ASM: Nachamkin I, Blaser MJ 22000, 467-48I.

2. Pattison M: Practical intervention strategies for Campylobacter. Symp Ser Soc Appl Microbiol 200I, 30:12I-I25.

3. Park SF: The physiology of Campylobacter species and its relevance to their role as foodborne pathogens. Int J Food Microbiol 2002, 74: 177-188.

4. Hänninen M-L, Haajanen H, Pummi T, Wermundsen K, Katila M-L, Sarkkinen H, Miettinen I and Rautelin H: Detection and typing of Campylobacter jejuni and Campylobacter coli and analysis of indicator organisms in three waterborne outbreaks in Finland. Appl Environ Microbiol 2003, 69:1391-1396. 
5. Schönberg-Norio D, Takkinen J, Hänninen $M-L$, Katila $M-L$, Kaukoranta S-S, Mattila L and Rautelin $\mathrm{H}$ : Swimming and Campylobacter infections. Emerg Infect Dis 2004, I 0: |474-I477.

6. Evans MR, Ribeiro CD and Salmon RL: Hazards of healthy living: Bottled water and salad vegetables as risk factors for Campylobacter infection. Emerg Infect Dis 2003, 9:1219-1225.

7. Potter RC, Kaneene JB and Hall WN: Risk factors for sporadic Campylobacter jejuni infections in Rural Michigan: a prospective case-control study. Am J Publ Health 2003, 93:2118-2123.

8. Luber $\mathrm{P}$ and Bartelt E: Enumeration of Campylobacter spp. on the surface and within chicken breast fillets. J Appl Microbiol 2007, 102:313-318.

9. Doyle MP: Association of Campylobacter jejuni with laying hens and eggs. Appl Environ Microbiol 1984, 47:533-536.

10. Shanker S, Lee A and Sorrell TC: Campylobacter jejuni in broilers: the role of vertical transmission. J Hyg 1986, 96: I53-159.

II. Jacobs-Reitsma WF: Aspects of epidemiology of Campylobacter in poultry. Vet $Q$ 1997, 19(3): I I3-117.

12. Buhr RJ, Cox NA, Stern NJ, Musgrove MT, Wilson JL and Hiett KL: Recovery of Campylobacter from segments of the reproductive tract of broiler breeder hens. Avian Dis 2002, 46:919-924.

13. Hiet KL, Cox NA and Stern NJ: Direct polymerase chain reaction detection of Campylobacter spp. in poultry hatchery samples. Avian Dis 2002, 46:219-223.

14. Petersen L, Nielsen EM and On SLW: Serotype and genotype diversity and hatchery transmission of Campylobacter jejuni in commercial poultry flocks. Vet Microbiol 200 I, 82: I4I-I54.

I5. Herman L, Heyndrick M, Grijspeerdt K, Vandekerchove D, Rollier I and De Zutter L: Routes for Campylobacter contamination of poultry meat: epidemiological study from hatchery to slaughterhouse. Epidemiol Infect 2003, I3 I: I I69-I I80.

16. Callicot KA, Friðriksdóttir V, Reiersen J, Lowman R, Bisaillon J-R, Gunnarsson E, Berndtson E, Hiett KL, Needleman DS and Stern NJ: Lack of evidence for vertical transmission of Campylobacter spp. in chickens. Appl Environ Microbiol 2006, 9:5794-5798.

17. Newell DG and Fearnley C: Sources of Campylobacter colonization in broiler chickens. Appl Environ Microbiol 2003 69:4343-435I.

18. Hald B, Skovgård H, Bang DD, Petersen K, Dybdahl J, Jespersen JB and Madsen M: Flies and Campylobacter infection of broiler flocks. Emerg Infect Dis 2004, I0(8): | 490-1492.

19. Johnsen $G$, Kruse $H$ and Hofshagen $M$ : Genetic diversity and description of transmission routes for Campylobacter on broiler farms by amplified-fragment length polymorphism. Appl Microbiol 2006, 10:1130-1139.

20. Bull SA, Allen VM, Dominique G, Jørgensen F, Frost JA, Ure R, Whyte R, Tinker D, Corry JEL, Gillard-King J and Humphrey TJ: Sources of Campylobacter spp. colonizing housed broiler flocks during rearing. Appl Environ Microbiol 2006, I:645-652.

21. Hald $B$, Sommer $H M$ and Skovgård $H$ : Use of fly screens to reduce Campylobacter spp. introduction in broiler houses. Emerg Infect Dis 2007, 13:1951-1953.

22. Berndtson E, Emanuelson U, Engvall $A$ and Danielsson-Tham ML: $\mathbf{A}$ I-year epidemiological study of Campylobacters in 18 Swedish chicken farms. Prev Vet Med 1996, 26:167-I85.

23. Perko-Mäkelä $P$, Hakkinen $M$, Honkanen-Buzalski $T$ and Hänninen $M$ L: Prevalence of Campylobacter in chicken flocks during the summer of 1999 in Finland. Epidemiol Infect 2000, 129:187-192.

24. Guerin MT, Wayne M, Reiersen J, Berke O, McEvan SA, Bisaillon J-R and Lowman R: A farm-level study of risk factors associated with the colonization of broiler flocks with Campylobacter spp. in Iceland, 200I-2004. Acta Vet Scand 2007, 49:18.

25. Stern NJ, Fedorka-Cray P, Bailey JS, Cox NA, Craven SE, Hiett KL, Musgrove MT, Ladely S, Cosby D and Mead GC: Distribution of Campylobacter spp. in selected U.S. poultry production and processing operations. J Food Prot 2001, 64:1705-1710.

26. Refrégier-Petton J, Rose N, Denis M and Salvat G: Risk factors for Campylobacter spp. contamination in French broiler-chicken flocks at the end of the rearing period. Prev Vet Med 200I, 50:89-100.

27. Cox NA, Stern NJ, Craven SE, Berrang ME and Musgrove MT: Prevalence of Campylobacter and Salmonella in the cecal droppings of turkeys during production. J Appl Poultry Res 2000, 9:542-545.

28. Wallace JS, Stanley KN and Jones K: The colonization of turkeys by thermophilic campylobacters. J Appl Microbiol 1998, 85:224-230.
29. Borck B: Campylobacter spp. in the Danish turkey production. PhD Thesis Danish Veterinary Institute and Department of Veterinary Microbiology, The Royal Veterinary and Agricultural University; 2003.

30. Slader J, Dominique G, Jorgensen F, McAlpine K, Owen RJ, Bolton F and Humprey T]: Impact of transport crate reuse and of catching and processing on Campylobacter and Salmonella contamination of broiler chickens. Appl Environ Microbiol 2002 , 68:7|3-7|9.

31. Hansson I, Ederoth M, Andersson L, Vågsholm I and Olsson Engvall E: Transmission of Campylobacter spp. to chickens during transport to slaughter. J Appl Microbiol 2005, 99: | |49-I I 57.

32. Berndtson E, Danielsson-Tham ML and Engvall A: Campylobacter incidence on a chicken farm and the spread of Campylobacter during the slaughter process. Int J Food Microbiol I986, 32:35-47.

33. Posch J, Feierl G, Wuest G, Sixl W, Schmidt S, Haas DU, Reinthaler FF and Marth E: Transmission of Campylobacter spp. in a poultry slaughterhouse and genetic characterisation of the isolates by pulsed-field gel electrophoresis. Brit Poult Sci 2006, 3:286-293.

34. Logue CM, Sherwood JS, Elijah LM, Olah PA and Docker MR: The incidence of Campylobacter spp. on processed turkey from processing plants in the Midwestern United States. J App Microbiol 2003, 95:234-24l.

35. Borck B and Pedersen K: Pulsed-field gel electroforesis types of Campylobacter spp. in Danish turkeys before and after slaughter. Int J Food Microbiol 2005, I 0 I:63-72.

36. Arsenault J, Letellier A, Quessy S, Morin J-P and Boulianne $M$ Prevalence and risk factors for Salmonella and Campylobacter spp. carcass contamination in turkeys slaughtered in Quebec, Canada. J Food Prot 2007, 6: I350-1359.

37. Atanassova V, Reich F, Beckmann L and Klein G: Prevalence of Campylobacter spp. in turkey meat from a slaughterhouse and in turkey meat retail products. FEMS Immunol Med Microbiol 2007, 49: |4|-|45.

38. Katzav M, Isohanni P, Lund M, Hakkinen M and Lyhs U: PCR assay for the detection of Campylobacter in marinated and nonmarinated poultry products. Food Microbiol 2008, 25:908-9|4.

39. Linton D, Owen RJ and Stanley J: Rapid identification by PCR of the genus Campylobacter and five Campylobacter species enteropathogenic for man and animals. Res Microbiol 1996 | 47:707-7|8.

40. Lund M, Nordentoft S, Pedersen K and Madsen M: Detection of Campylobacter spp. in chicken fecal samples by real-time PCR. J Clin Microbiol 2004, 42:5 I25-5I 32.

41. Gibello MM, Blanco MA, Moreno MT, Cutuli A, Domenech L, Domínguez $C$ and Fernández-Garayzábal JF: Development of a PCR assay for detection of Yersinia ruckeri in tissues of inoculated and naturally infected trout. Appl Environ Microbiol 1999, 65:346-350.

42. National Committee of Food Analyses: Thermotolerant Campylobacter. Detection, semi-quantitative and quantitative determination in foods and drinking water. NCFA method no. I/ 932007.

43. Vandamme P, Van Doorn L-J, Al Rashid ST, Quint WGV, Plas Van Der J, Chan VL and On SLW: Campylobacter hyoilei Alderton et al. 1995 and Campylobacter coli Véron and Chatelain 1973 are subjective synonyms. Int ] Syst Bacteriol 1997, 47: 1055-1060.

44. Smith RD: Veterinary clinical epidemiology Florida: CRC Press Inc; 1995.

45. Martin SW, Meek $\mathrm{AH}$ and Willberg $\mathrm{P}$ : Veterinary epidemiology, principles and methods lowa: lowa State University Press; 1997.

46. Hald B, Rattenborg E and Madsen M: Role of batch depletion of broiler houses on the occurrence of Campylobacter spp. in chicken flocks. Lett Appl Microbiol 200I, 4:253-256.

47. Jacobs-Reitsma W, Wilpshaar E, Gussinklo B, Wagenaar J and Stegeman A: Epidemiological investigations into the colonisation of Dutch broiler flocks with Campylobacter. Int J Med Microbiol 2001, 291:42-43.

48. Anonymous: Interactions to control Campylobacter in the broiler production. Report of an international expert consultation. Copenhagen, Denmark, 26-27 November 2007Rosenquist H, Boysen L, Borck B I http://www.food.dtu.dk.

49. Russa AD, Bouma A, Vernooij JCM, Jacobs-Reitsma $W$ and Stegeman JA: No association between partial depopulation and Campylobacter spp. colonization of Dutch broiler flocks. Lett Appl Microbiol 2005, 41:280-285.

50. Hansson I, Vågsholm I, Svensson L and Olsson Engvall E: Correlations between Campylobacter spp. prevalence in the environment and broiler flocks. J Appl Microbiol 2007, 103:640-649. 
5I. Allen VM, Bull SA, Corry JEL, Dominigue GJ, Jørgensen F, Frost JA, Whyte R, Conzales A, Elviss $\mathrm{N}$ and Humphrey TJ: Campylobacter spp. contamination of chicken carcasses during processing in relation to flock colonisation. Int J Food Microbiol 2007, | | 3:54-6|.

52. Peyrat MB, Soumet C, Maris P and Sanders P: Phenotypes and genotypes of Campylobacter strains isolated after cleaning and disinfection in poultry slaughterhouses. Vet Microbiol 2008, I 28:313-326.

53. Jeffrey JS, Tonooka KH and Lozanot J: Prevalence of Campylobacter spp. from skin, crop, and intestine of commercial broiler chicken carcasses at processing. Poult Sci 200I, 80: 1390-1392.

54. Cools I, Uyttendaele M, Cerpentier J, D'Haese E, Nelis HJ and Debevere J: Persistence of Campylobacter jejuni on surfaces in a processing environment and on cutting boards. Lett Appl Microbiol 2005, 40:418-423.

55. Sanders SQ, Boothieet DH, Frank JF and Arnold JW: Culture and detection of Campylobacter jejuni within mixed microbial populations of biofilms on stainless steel. J Food Prot 2007, 70 (6): I 379-1385.

56. Sanchez MX, Fluckey WM, Brashears MM and McKee SR: Microbial profile and antibiotic susceptibility of Campylobacter spp. and Salmonella spp. in broilers processed in air-chilled and immersion-chilled environments.. J Food Prot 200I, 65:948-956.

57. Klein G, Reich F, Beckman L and Atanassova V: Quantification of thermophilic Campylobacter spp. in broilers during meat processing. Antonie van Leeuwenhoek 2007, 92:267-273.

58. Alter T, Gaull F, Froeb $A$ and Fehlhaber K: Distribution of Campylobacter jejuni strains at different stages of a turkey slaughter line. Food Microbiol 2005, 22:345-35I.

59. Hänninen M-L, Perko-Mäkelä P, Pitkälä $A$ and Rautelin H: A threeyear study of Campylobacter jejuni genotypes in humans with domestically acquired infections and in chicken samples from the Helsinki area. J Clin Microbiol 2000, 38: I998-2000.

60. Hamedy A, Alter T, Schlichting $D$, Ludewig $M$ and Fehlhaber $K$ : Quantitative detection of Campylobacter spp. on turkey carcasses and turkey meat. Fleischwirtsch 2000, 87:I2I-I24.

61. Takahashi R, Shahada F, Chuma T and Okamoto K: Analysis of Campylobacter spp. contamination in broilers from the farm to the final meat cuts by using restriction fragment length polymorphism of the polymerase chain reaction products. Int J Food Microbiol 2006, I I 0:240-245.

Publish with Biomed Central and every scientist can read your work free of charge

"BioMed Central will be the most significant development for disseminating the results of biomedical research in our lifetime. "

Sir Paul Nurse, Cancer Research UK

Your research papers will be:

- available free of charge to the entire biomedical community

- peer reviewed and published immediately upon acceptance

- cited in PubMed and archived on PubMed Central

- yours - you keep the copyright

Submit your manuscript here:

http://www.biomedcentral.com/info/publishing_adv.asp
BioMedcentral 